\title{
10th Anniversary of Water
}

\author{
Jeroen C. J. H. Aerts
}

Institute for Environmental Studies (IVM), VU University Amsterdam, De Boelelaan 1087, 1081HV Amsterdam, The Netherlands; jeroen.aerts@vu.nl

Received: 28 April 2020; Accepted: 10 May 2020; Published: 12 May 2020

check for updates

\begin{abstract}
This Special Issue was set up to mark the 10th anniversary of Water. The contributions to this Special Issue of Water were carefully selected by the late Guest Editor Prof. Dr. Arjen Hoekstra. Arjen was devoted to conducting excellent science and was motivated to create this Special Issue to be something 'special'. It was therefore dedicated to the publication of 11 comprehensive papers and reviews encompassing the most significant developments in the realm of water sciences in the last decade.
\end{abstract}

Keywords: Governance; flood adaptation costs; hydro-informatics; water management; water use

\section{Introduction}

Water is essential to all life on earth, but its management is facing increasing challenges due to socio-economic pressures such as population growth and the unsustainable use of water resources. Climate change will further exacerbate the water risk for society and the environment, and water-related extremes such as floods and droughts will increase in the future. The long-term aspects of these future trends and the inherent uncertainty within future projections present water managers with considerable challenges. The technocratic approach of working with fixed design standards for engineering seems insufficient; the environment is constantly changing, and, as a consequence of this, so too are the boundary conditions on which basis engineered water management solutions are developed. Therefore, water management is increasingly developing into an adaptive form of decision making, where flexibility, robustness and resilience are key [1]. Moreover, societal processes and the physical water system are increasingly interwoven, and there are little natural water systems not influenced by human activity. These developments require novel approaches in decision sciences, data processing, modelling techniques, catalyzed by the integration of social and natural sciences [2]. The international journal Water addresses these challenges as an outlet for cutting-edge inter-disciplinary approaches in water science. In this Special Issue, topics cover broad aspects of water systems, including water science, water quality, management, and governance.

\section{Overview of the Special Issue}

Grafton, R.Q., et al. [3] demonstrate the use of a new water governance reform framework (WGRF), which may help authorities to reform their governance frameworks to achieve convergence between water supply and demand and ensure freshwater ecosystem services are sustained. The importance of water governance is further illustrated in a paper by Purkey, D.R., et al. [4] that tries to answer the question of whether the best option even exists. Although such existential questions are not common in the water management community, they are not new to political theory. This paper explores early classical writing related to issues of knowledge and governance, as captured in the work of Plato and Aristotle, and then attempts to place a novel, analysis-supported, and stakeholder-driven water resources planning and decision-making practice within this philosophical discourse, referencing current decision theory. 
Koech, R., and Langat, P.'s, [5] paper on irrigation reviews the advancements toward improving irrigation water use efficiency (WUE), with a focus on irrigation in Australia, but with some examples from other countries. The review shows that improvements in irrigation infrastructure through modernization and automation have led to water savings, and that the future is likely to see increased use of remote sensing techniques, wireless communication systems, and more versatile sensors to improve WUE.

A review paper by Aerts, J.C.J.H., [6] on the cost of flood adaptation measures provides the most recent empirical data regarding the cost of flood management by compiling peer-reviewed literature and research reports. The focus is on construction costs and expenses for operation and maintenance, including: (1) the flood-proofing of buildings, (2) flood protection, (3) beach nourishment and dunes, (4) nature-based solutions for coastal ecosystems, (5) channel management and nature-based solutions for riverine systems, and (6) urban drainage.

Related to urban drainage in the previous review, another contribution by Antunes, L.N., et al. [7] presents an overview of permeable pavements and studies of life cycle assessment that compare the environmental performance of permeable pavements with traditional drainage systems. Life cycle assessment studies are essential to guide planning and decision making, leading to systems that consider increasing water resources and reducing natural disasters and environmental impacts.

Further within the context of river management options, a paper on river relocation by Flatley, A., et al. [8] discusses shortcomings in current practice for river relocation and highlights areas for future research for the successful rehabilitation of relocated rivers. Relocations are common through history, carried out for a wide range of purposes, but most commonly to construct infrastructure and for mining. However, many assessment studies do not include the effects of climate change.

Another paper by Makropoulos, C., and Savić, D.A., [9] provides a comprehensive overview of the history of hydroinformatics. Hydroinformatics has arguably been able to mobilize wide ranging research and development and align the water sector more with the digital revolution of the past 30 years. In this context, this paper attempts to trace the evolution of the discipline from its computational hydraulics origins to its present focus on the complete socio-technical system and by providing a framework to highlight the links between different strands of the state-of-art hydroinformatic research and innovation.

A paper by Iaccarino, M. [10] on population growth and water use touches upon a very timely issue: the influence of water contamination on the human population. The paper considers historic data and shows that after a huge population increase between the years 25,000 and 5000 Before Common Era (BCE), the number of people did not change appreciably after 200 Common Era (CE), and increased only slowly in the period 1000 to $1500 \mathrm{CE}$. The authors show that the main cause of this observed slow-down in population growth was the increase in population density, which caused the appearance and spreading of infectious diseases, often due to the use of contaminated water.

Another paper by Destouni, G. and Prieto, C. [11] develops a data-driven approach to robustly assess freshwater changes due to climate change and/or human irrigation developments using the overarching constraints of catchment water balance. The results show that the resulting uncertainties in the water-balance constrained estimates of runoff and evapotranspiration $(E T)$ changes are smaller than the input data uncertainties.

A paper by Hynds, P. et al. [12] on socio-hydrogeology, an extension of socio-hydrology, emphasises a bottom-up methodology involving non-expert end-users in hydrogeological investigations. The authors consider that multiple actors should be identified and incorporated using stakeholder network analysis, which may include policymakers, media and communications experts, mobile technology developers, and social scientists, to appropriately convey demographically focused bi-directional information, with the hydrogeological community representing the communication keystone.

The final paper by Clifford, C.C. and Heffernan, J.B., [13] analyzes the importance of artificial aquatic systems in modern landscapes. The provisioning of ecosystem services by these systems is underexplored and likely underestimated. Instead of accepting that artificial ecosystems have intrinsically low values, 
environmental scientists should determine what combination of factors, including setting, planning, and construction, affects these values. Scientists, social scientists, and policymakers should more thoroughly evaluate whether current study and management of artificial aquatic systems are based on the actual ecological condition of these systems, or judged differently, due to artificiality, and consider the possible resultant changes in goals for these systems.

\section{Conclusions}

The papers in this Special Issue are, of course, not reflecting all the recent developments in water sciences. However, it provides a snap-shot of important scientific developments required to support water managers in their endeavor to deal with increasing complexity and uncertainty. As such, Arjen would be proud of the result of this Special Issue, as all articles contribute to the much needed debate around the fair and sustainable allocation of fresh water resources [14].

Acknowledgments: All acknowledgements for making this special issue a success are for the late Arjen Hoekstra, guest editor of this Special Issue, and a devoted and inspiring researcher.

Conflicts of Interest: The author declares no conflict of interest.

\section{References}

1. Becker, G.; Huitema, D.; Aerts, J.C. Prescriptions for adaptive co-management: the case of flood management in the German Rhine basin. Ecology and Society 2015, 20. [CrossRef]

2. Aerts, J.C.J.H.; Botzen, W.J.; Clarke, K.; Cutter, S.L.; Michel-Kerjan, E.; Surminski, S.; Mysiak, J.; Merz, B.; Hall, J.; Kunreuther, H. Including Human Behavior in Flood risk assessment. Nat. Clim. Chang. 2018, 8, 193-199.

3. Grafton, R.Q.; Garrick, D.; Manero, A.; Do, T.N. The Water Governance Reform Framework: Overview and Applications to Australia, Mexico, Tanzania, U.S.A and Vietnam. Water 2019, 11, 137. [CrossRef]

4. Purkey, D.R.; Escobar Arias, M.I.; Mehta, V.K.; Forni, L.; Depsky, N.J.; Yates, D.N.; Stevenson, W.N. A Philosophical Justification for a Novel Analysis-Supported, Stakeholder-Driven Participatory Process for Water Resources Planning and Decision Making. Water 2018, 10, 1009. [CrossRef]

5. Koech, R.; Langat, P. Improving Irrigation Water Use Efficiency: A Review of Advances, Challenges and Opportunities in the Australian Context. Water 2018, 10, 1771. [CrossRef]

6. Aerts, J.C.J.H. A Review of Cost Estimates for Flood Adaptation. Water 2018, 10, 1646. [CrossRef]

7. Antunes, L.N.; Ghisi, E.; Thives, L.P. Permeable Pavements Life Cycle Assessment: A Literature Review. Water 2018, 10, 1575. [CrossRef]

8. Flatley, A.; Rutherfurd, I.D.; Hardie, R. River Channel Relocation: Problems and Prospects. Water 2018, 10, 1360. [CrossRef]

9. Makropoulos, C.; Savić, D.A. Urban Hydroinformatics: Past, Present and Future. Water 2019, 11, 1959. [CrossRef]

10. Iaccarino, M. Water, Population Growth and Contagious Diseases. Water 2019, 11, 386. [CrossRef]

11. Destouni, G.; Prieto, C. Robust Assessment of Uncertain Freshwater Changes: The Case of Greece with Large Irrigation-and Climate-Driven Runoff Decrease. Water 2018, 10, 1645. [CrossRef]

12. Hynds, P.; Regan, S.; Andrade, L.; Mooney, S.; O’Malley, K.; DiPelino, S.; O’Dwyer, J. Muddy Waters: Refining the Way forward for the "Sustainability Science" of Socio-Hydrogeology. Water 2018, 10, 1111. [CrossRef]

13. Clifford, C.C.; Heffernan, J.B. Artificial Aquatic Ecosystems. Water 2018, 10, 1096. [CrossRef]

14. Vanham, D.; Mekonnen, M.M.; Chapagain, A.K. Arjen Y. Hoekstra 1967-2019. Nat. Sustain. 2020, 3, 80. [CrossRef]

(C) 2020 by the author. Licensee MDPI, Basel, Switzerland. This article is an open access article distributed under the terms and conditions of the Creative Commons Attribution (CC BY) license (http://creativecommons.org/licenses/by/4.0/). 